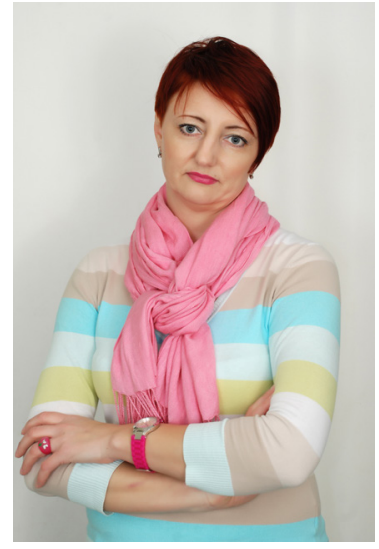

\section{Оксана Самойленко,}

кандидат педагогічних наук, докторант кафедри педагогіки, Житомирський державний університет імені Івана Франка (Житомир, Україна)

Oksana Samoilenko, $\mathrm{PhD}$ in Education, doctoral student of the chair of pedagogy, Zhytomyr Ivan Franko State University (Zhytomyr, Ukraine) samoilenckooxana@gmail.com ORCID ID 0000-0002-2305-4111

\title{
ТЕНДЕНЦІЇ РОЗВИТКУ ОСВІТИ ДОРОСЛИХ НА ПОЧАТКУ ХХІ СТОЛІТТЯ: ДОСВІД СЛОВАЦЬКОЇ РЕСПУБЛІКИ
}

Анотація. Сучасний світ постулює тенденцію до неперервності в освіті дорослих, тривалості впродовж життя. Питання освіти дорослих на часі в освітній політиці країн європейської співдружності: вона виступає чинником підвищення якості життя громадян. Україна з її прагненням стати повноправним членом Європейського Союзу потребує вивчення досвіду європейських країн щодо освіти дорослих задля його екстраполяції. Словацька Республіка в цьому контексті може виступити орієнтиром для впровадження реформ у вітчизняну сферу освіти дорослих.

Метою статті $€$ аналіз тенденцій розвитку освіти дорослих на початку XXI століття у Словацькій Республіці на тлі європейського досвіду. Методи дослідження: на основі аналізу та систематизації статистичної інформації, нормативноправових документів, теоретичних напрацювань словацьких науковців здійснено узагальнення тенденцій розвитку освіти дорослих у Словацькій Республіці на початку XXI століття.

Виявленні в ході дослідження тенденції розвитку освіти дорослих на початку XXI століття показують суспільну затребуваність у адаптації наявного освітнього контенту до модерних викликів сьогодення. Досвід Словацької Республіки підтверджує ефективність євроінтеграційної спрямованості розвитку освіти дорослих у політиці підвищення конкурентоспроможності фахівця на ринку праці.

Ключові слова: неперервна освіта, освіта дорослих, тенденції розвитку, глобальне освітнє інноваційне середовище.

\section{DEVELOPMENT TRENDS FOR ADULT EDUCATION AT THE BEGINNING OF THE XXI CENTURY: THE EXPERIENCE OF THE SLOVAK REPUBLIC}

Abstract. The modern world postulates the tendency towards continuity in adult education, life expectancy. The question of adult education in time in the educational policy of the countries of the European Commonwealth: it acts as a factor in increasing the bone of life of citizens. Ukraine, with its aspirations to become a full member of the European Union, needs to study the experience of European countries in adult education in order to extrapolate it. In this context, the Slovak Republic can serve as a benchmark for introducing reforms into the domestic adult education field.

The purpose of the article is to analyze the trends of adult education at the beginning of the XXI century in the Slovak Republic against the backdrop of European experience. Methods of research: on the basis of analysis and systematization of statistical information, normative legal documents, theoretical developments of Slovak scholars, a generalization of trends in the development of adult education in the Slovak Republic at the beginning of the 21st century.

Identified during the study of trends in the development of adult education in the early 21 st century show the public demand in adapting the existing educational content to the modern challenges of the present. The experience of the Slovak Republic confirms the effectiveness of the Eurointegration orientation of adult education development in the policy of increasing the competitiveness of a specialist in the labor market.

Keywords: continuous education, adult education, development tendencies, global educational innovation environment..

\section{ВСТУП}

Постановка проблеми. Сучасний світ постулює тенденцію до неперервності в освіті дорослих, тривалості впродовж життя. Неперервна освіта дорослих у країнах європейського простору розглядається як засада активного навчання, яке не ґрунтується винятково на передачі знань, а, навпаки, фокусується на реальному досвіді дорослої людини, визнаючи цінність знань та умінь, відповідно до набутих. «Країни-члени ЄС більше не 
можуть існувати без ефективної системи освіти дорослих, інтегрованої у стратегію навчання протягом усього життя, що забезпечує учасникам дедалі ширші можливості виходу на ринок праці, поліпшення соціальної інтеграції та підготовку до «активного старіння» у майбутньому», - зазначають науковці (Petrides L., \& Jimes C., 2008). Це не «безперервна» школа, а освітня система, яка чергується з періодами праці, професійного становлення, активних життєвих циклів та періодами особистої неактивності дорослої людини. Неперервна освіта дорослих - це освітній процес, який триває все життя, у якому важливу роль відіграє інтеграція індивідуальних та соціальних планів.

Аналіз останніх досліджень і публікацій. Питання освіти дорослих на часі в освітній політиці країн європейської співдружності, підтвердженням чого є визначення її пріоритетності у Стратегії розвитку Європейського Союзу «Європа 2020» (Europe 2020, 2010). Вітчизняні та зарубіжні науковці не залишаються осторонь модерних освітніх тенденцій і аналізують їх у перспективі змін інновацій, технологій та прогнозів (В. Андрущенко, О. Аніщенко, О. Вовк, І. Зязюн, О. Дубасенюк, М. Євтух, В. Кремень, Л. Лук'янова, Л. Сігаєва, В. Шинкаренко, О. Шапочкіна та ін.).

META I ЗАВДАННЯ ДОСЛІДЖЕННЯ - проаналізувати тенденції розвитку освіти дорослих на початку XXI століття в контексті досвіду європейських країн, зокрема Словацької Республіки.

МЕТОДИ ДОсЛІДЖЕННЯ: на основі аналізу та систематизації статистичної інформації, нормативноправових документів, теоретичних напрацювань словацьких науковців здійснено узагальнення тенденцій розвитку освіти дорослих у Словацькій Республіці на початку XXI століття.

\section{РЕЗУЛЬТАТИ ДОСЛІДЖЕННЯ}

Словацька Республіка як країна-член європейської співдружності має осібний досвід розвитку освіти дорослих з урахуванням напрацювань у сфері освітньої політики Європейського Союзу. Для України цей досвід цікавий у контексті наближеності процесів суспільно-політичного, культурного та економічного характеру до реалій становлення Словаччини як європейської держави (2004). Аналіз практики розвитку освіти дорослих за останні п'ятнадцять років у цій країні показує стрімкість її формування як ефективного соціального інституту забезпечення професійної самореалізації дорослої людини.

Зважаючи на етапи розвитку освіти дорослих у Словаччині, трансформацію змісту та цілей освіти дорослих у країнах Європейського Союзу, основною тенденцією розвитку освіти дорослих на початку XXI століття визначено євроінтеграційну спрямованість освіти загалом і освіти дорослих зокрема. Глобалізація, інтернаціоналізація та інформатизація суспільних процесів призвели до появи своєрідних трендів в освіти дорослих, зокрема:

1. Поява глобального інноваційного освітнього середовища, яке створює знання негайно, у режимі реального часу. Цей вид контенту називають відкритим освітнім ресурсом (ВОР).

Володіючи необмеженим поширенням і доступністю технології, ВОР має значний потенціал для створення спільноти користувачів, які використовують, діляться і постійно доповнюють відкриті освітні ресурси інформацією, удосконалюючи тим самим зміст освіти (Benkler Y., 2005). Цей процес двосторонньо спрямований: створення інформаційно-насиченого контенту дозволяє підтримувати ВОР у актуальному стані і створювати нові відкриті освітні ресурси (Petrides L., \& Jimes C., 2008). Перевага BOP як джерела змісту освіти полягає в тому, що спільні тимчасові робочі групи (ad-hoc групи), які беруть участь у регулярному і змістовному насиченні ВОР, ефективніше працюють, аніж автори, які працюють одноосібно. Окрім того, ВОР можуть містити особисті рекомендації, відображають ціннісні орієнтації та практичний досвід авторів. У цьому сенсі відкриті освітні ресурси соціальні і сприяють розвитку освіти дорослих, перетворюються вже на масові відкриті онлайн-курси (Massive open online course - MOOC).

Відкриті інтернет-джерела анонсують, що МООС дозволяють пройти навчання у викладачів провідних світових університетів - людей, які мають вагу в академічному світі, влитися в мультинаціональну студентську групу (на дискус-форумах), отримати документ, що підтверджує успішне проходження всього курсу. Найбільші онлайнплатформи викладають відеоматеріали та проводять оцінювання отриманих знань. Різниця в тому, які саме курси пропонуються, хто і як їх читає («Популярні платформи онлайн-курсів (МООС)»).

2. Розширення можливостей неформальної та інформальної освіти, які виявилися реакцією на поширення в суспільстві тенденції до зміни парадигми навчання 3 «людини, яка багато знає», до парадигми «людини з орієнтацією на цінність освіти як провідного виду діяльності в структурі власного способу життя» (Укис Ю., 2005). Це пов'язано з необхідністю розв'язання проблеми невідповідності наявних систем освіти розвитку інформаційного суспільства і виникненням у наукових колах сумнівів у необхідності систематизованої передачі знань, умінь і цінностей.

Реалізація можливостей неформальної та інформальної освіти дорослих вимагає нової стратегії освіти, заснованої на її ефективності, зумовленої:

1) високим ступенем мотивації дорослого, тому що спонукальні причини до продовження навчання приховані не стільки в зовнішніх примусових умовах, скільки у внутрішніх імпульсах людської особистості, якими можуть бути інтеріорізовані, осмислені і прожиті зовнішні чинники;

2) цілеспрямованістю, свідомістю навчальної діяльності дорослого, що базується здебільшого на самостійному навчанні;

3) цілями навчання; 
4) гнучкістю, яка необхідна для задоволення різноманітних індивідуальних потреб дорослих через використання аудіо- і відеозасобів, друкованої продукції як варіативних форм зв'язку з учнями;

5) відносно невисокою платою за навчання (порівняно зі школами, закладами вищої освіти та ін.);

6) гнучкою системою фінансування неформальної освіти.

Сучасне бачення особливостей неформальної освіти дорослих представлено на сайті Європейської асоціації освіти дорослих: «Спеціально організована діяльність зі сприяння процесу, у межах якого люди можуть свідомо розвиватися як особистості, самостійно спиратися на власні можливості в соціальних відносинах і діяльності за допомогою підвищення рівня знань і розуміння; співвіднесення власних думок і почуттів з думками і почуттями інших людей; розвиток умінь і способів їх вираження» (Нежинська О. О., 2017).

Тому неформальна освіта дорослих у Словаччині розглядається як будь-який вид організованої і систематичної діяльності, що не збігається з діяльністю шкіл, університетів та інших закладів освіти, що входять до складу формальної системи освіти; як така, що здобувається у післяробочий час в освітніх закладах, клубах, гуртках і зазвичай не передбачає отримання офіційного документа. Розвиток теорії неформальної та інформальної освіти у Словацькій Республіці здійснюється з урахуванням принципів її організації, визначених «Меморандумом неперервної освіти» країн Європи («Меморандум непрерывного образования Европейского Союза»):

- нові базові знання та навички для всіх як гарантія загального неперервного доступу до освіти з метою отримання і оновлення навичок, необхідних для включення в інформаційне суспільство;

- збільшення інвестицій у людські ресурси, що ставить за мету підняти престиж і позначити пріоритет найважливішого для Європи надбання - людей;

- інноваційні методики викладання і навчання для системи неперервної освіти «завдовжки і завширшки» в життя, за допомогою яких дорослий учень перестає бути пасивним реципієнтом інформації, а викладачі перетворюються на консультантів, наставників і арбітрів;

- нова система оцінки отриманої освіти, покликана докорінно змінити підходи до визнання результатів навчальної діяльності у сфері неформальної та інформальної освіти;

- розвиток наставництва і консультування, які сприяють забезпеченню вільного доступу до інформації про освітні можливості в просторі Європи;

- наближення освіти до дорослого учня за допомогою мережі навчальних і консультаційних пунктів, а також інформаційних технологій.

У Словаччині неформальна освіта дорослих представлена діяльністю громадських (Асоціація навчальних закладів для дорослих у Словацькій республіці (AIVD SR), Асоціація університетів третього віку (ASUTV), Acoціація тренерів та консультантів з кар'єри (ALKP), Асоціація працедавців та фахових організацій Словацької республіки (AZZZ SR), Платформа організацій неурядового розвитку (MVRO), Спілка працедавців Словацької республіки (RUZ), Словацька академічна асоціація з навчання впродовж життя (SAACV), Словацька академічна асоціація з міжнародного співробітництва (SAAIC), Асоціація з кар'єрного розвитку та порадництва (ZPKPRK)) та державних (Державний інститут професійної освіти (SAAIC), Національне агентство Erasmus+) інституцій. Метою їх практик $€$ «розробка ефективних методів навчання дорослих у контексті неперервної ціложиттєвої освіти» (Николенко Л.). Акцент у системі неформальної освіти Словацької республіки робиться на дорослому учневі, якому слід надати найширшу пропозицію перспектив навчання та засобів його забезпечення.

3. Посилення ролі організацій, відповідальних за сертифікацію результатів навчання. Онлайн-освіта перебирає на себе функції стандартних навчальних закладів. А значить, буде запозичувати і відповідні стандарти: класифікацію і ранжування освітніх центрів. Якість викладання і працю спеціалістів у галузі освіти дорослих експерти оцінюватимуть за низкою показників, формуючи об'єктивні рейтинги. У такому разі сертифікати курсів з сумнівного папірця перетворяться на доказ отриманих знань: із часом вони стануть рівноцінними результатами іспитів закладів вищої освіти. Провайдери освітніх курсів будуть змушені ретельніше добирати лекторів і дбати про свою репутацію.

Словацька Республіка має досвід визнання результатів неформальної та інформальної освіти через систему валідації - процес ідентифікації, визнання та сертифікації попереднього навчання, який спрямований на те, щоб надати можливість дорослій людині (індивіду) визнати свої компетенції незалежно від того, як, де і коли було раніше здобуто освіту, отримано вміння та навички певної кваліфікації. У цьому процесі знання, здобутті в різних контекстах, стають видимими, ідентифікованими, оціненими та прийнятими: офіційне визнання надається. У сфері освіти і підготовки компетентності визнаються відповідно до кваліфікаційних вимог або навчальної програми, тоді як у процесі життєзабезпечення валідація приводить до підвищення заробітної плати або виконання більш відповідальних, вимогливих і складних обов'язків (Мелешко І.В., 2018, с. 24).

Метою валідації результатів неформальної та інформальнох освіти є (Detko J, Fonodovб I., Gбllovб L., Klempovб M. Lasz A., prlбk T., 2016):

- сприяння мобільності фахівців на ринку праці, надаючи особам доступ до навчання та визнання набутих знань, умінь та компетенцій;

- підвищення ефективності освіти та навчання за допомогою забезпечення рівного доступу до освіти;

- підвищення рівності можливостей для дорослих у досягненні визнання їх компетенцій, незалежно від того, де вони їх набули і, у цьому контексті, підтримка уразливих груп населення, безробітних, людей поважного віку та ін.; 
- стимулювати навчання протягом усього життя через забезпечення прогресивної перевірки набутих знань, навичок та інших компетенцій;

- забезпечення викликів демографічних змін та ін.

Питання визнання результатів неформальної та інформальної освіти у Словацькій Республіці постало у зв'язку із формуванням Радою Європейського Союзу Рекомендацій щодо валідації результатів неформальної та інформальної освіти (20 грудня 2012 року) - validation of non-formal and informal learning (VNIU) («Council recommendation of 20 December 2012 on the validation of non-formal and informal learning»). У динамічно змінюваних умовах ринку праці кожен елемент системи освіти дорослих повинен бути готовим гнучко реагувати на зміни: дорослий учень (часто на посаді працівника чи пошукача роботи), педагог/андрагог, навчальні заклади (як провайдери освітніх послуг), працедавець та служба зайнятості (як складники професійної зайнятості дорослого).

\section{ВИСНОВКИ ТА ПЕРСПЕКТИВИ ПОДАЛЬШИХ ДОСЛІДЖЕНЬ}

Виявленні в ході дослідження тенденції розвитку освіти дорослих на початку XXI століття показують суспільну затребуваність у адаптації наявного освітнього контенту до модерних викликів сьогодення. Досвід Словацької Республіки підтверджує ефективність євроінтеграційної спрямованості розвитку освіти дорослих у політиці підвищення конкурентоспроможності фахівця на ринку праці.

Адаптація позитивного досвіду освіти дорослих Словаччини до вітчизняних реалій уможливлює наміри України стати повноправним членом Європейського Союзу, у якому освіта дорослих визнається ключовим чинником підвищення якості життя громадян. Тому перспективним вважаємо дослідження напрямів екстраполяції словацького досвіду для розвитку освіти дорослих в Україні.

\section{СПИСОК ВИКОРИСТАНИХ ДЖЕРЕЛ}

Benkler, Y., (2005). Common wisdom: Peer production of educational materials. Utah: COSL Press, Utah State University. URL: ttp:// www.benkler.org/Common_Wisdom.pdf

Council recommendation of 20 December 2012 on the validation of non-formal and informal learning. Oficial Journal 2012/C 398/01. URL: http://eur-lex.europa.eu/LexUriServ/LexUriServ.do?uri=OJ:C:2012:398

Detko, J, Fonodová, I., Gállová, L., Klempová, M. Lasz ,A., Šprlák, T., (2016). Validácia výsledkovneformálnehovzdelávania ainformálneho učenia sav SR. Bratislava, november. $70 \mathrm{~s}$.

Europe 2020, (2010). A strategy for smart sustainable and inclusive growth: [online]. European Comission. Access Mode: URL: https: //ec.europa.eu/europe2020/index_en.htm.

Petrides, L., \& Jimes, C. (2008b). Travel well open educational resources: A presentation of ongoing research. Powerpoint presentation at i Summit. Sapporo, Japan. August.

Абдулкеримов, И. З., (2011). Факторы и условия развития интеграционных процессов на рынке образовательных услуг. Региональные проблемы преобразования экономики, 2 (28), 286-292.

Мелешко І.В., (2018). Визнання результатів неформальної освіти дорослих у Фінляндії: особливості і механізми. Педагогічні науки: збірник наукових праць. Випуск LXXXII. Том 1. 23-26.

Меморандум непрерывного образования Европейского Союза. URL: http://www.znanie.org/jornal/n1_01/nepreriv_obraz.html

Нежинська О. О., (2017). Основи коучингу : навчальний посібник. Київ ; Харків : ТОВ «ДІСА ПЛЮС».

Николенко Л. Образование взрослых в Швеции. URL http://www.pandia.ru/text/78/006/38343.php

Популярні платформи онлайн-курсів (МОOC). URL: http://osvita.ua/abroad/higher_school/distance-learning/37601

Укис Ю. А., (2005). Роль неформальных институтов в переходной экономической системе. (Кандидатская диссертация). Харьков.

\section{REFERENCES}

Benkler, Y., (2005). Common wisdom: Peer production of educational materials. Utah: COSL Press, Utah State University. Retrieved from: ttp://www.benkler.org/Common_Wisdom.pdf

Council recommendation of 20 December 2012 on the validation of non-formal and informal learning. Oficial Journal 2012/C 398/01. Retrieved from: http://eur-lex.europa.eu/LexUriServ/LexUriServ.do?uri=OJ:C:2012:398

Detko, J, Fonodová, I., Gállová, L., Klempová, M. Lasz, A., Šprlák, T. (2016) Validácia výsledkovneformálnehovzdelávania ainformálneho učenia sav SR. Bratislava, november. 70.

Europe 2020, (2010). A strategy for smart sustainable and inclusive growth: [online]. European Comission. Retrieved from: https: // ec.europa.eu/europe2020/index_en.htm.

Petrides, L., \& Jimes, C. (2008b). Travel well open educational resources: A presentation of ongoing research. Powerpoint presentation at iSummit. Sapporo, Japan, August.

Abdulkerymov, Y. Z., (2011). Faktory i usloviya razvitiya integratsionnykh protsessov na rynke obrazovatelnykh uslug. Regionalnye problemy preobrazovaniya ekonomiki. 2 (28), 286-292.

Meleshko, I.V., (2018). Vyznannia rezultativ neformalnoi osvity doroslykh u Finliandii: osoblyvosti i mekhanizmy. Pedahohichni nauky: zbirnyk naukovykh prats. Vypusk LXXXII. Vol. 1. 23-26.

Memorandum nepreryvnogo obrazovaniya Yevropeyskogo Soyuza.. Retrieved from: http://www.znanie.org/ jornal/n1_01/nepreriv_obraz.html

Nezhynska, O. O., (2017). Osnovy kouchynhu : navchalnyi posibnyk. Kyiv ; Kharkiv : TOV «DISA PLluS».

Nykolenko, L. Obrazovanie vzroslykh v Shvetsii. Retrieved from: http://www.pandia.ru/text/78/006/38343.php

Populiarni platformy onlain-kursiv (MOOC). Retrieved from: http://osvita.ua/abroad/higher_school/distance-learning/37601

Ukys, Yu. A., (2005). Rol neformalnykh institutov v perekhodnoy ekonomicheskoy sisteme. (Candidate's thesis). Kharkov. 